\title{
Towards a "Wider Mandate" of Pesantren: IN SEARH FOR A NEW NOMENCLATURE OF POLITICAL ROLE OF PESANTREN IN AN ERA OF DEMOCRACY ${ }^{1}$
}

\author{
Masdar Hilmy \\ IAIN Sunan Ampel Surabaya \\ Email: masdar_hilmy@yahoo.com
}

\section{Abstrak}

Makalah ini berusaha menganalisis tren kontemporer sebagian besar pesantren Indonesia dalam konteks pasca pemilihan presiden. Bahwa keberadaan pesantren tidak bisa memisahkan diri dari konfigurasi politik Indonesia. Politik dalam pesantren dapat dilihat sebagai modalitas pesantren untuk mencapai kehidupan publik lebih baik. Namun demikian, sebagian besar pesantren menyadari bahwa melibatkan diri dalam politik praktis dapat merusak citra dan kemandirian sebagai agen transformasi sosial. Oleh karena itu, pesantren perlu mempertimbangkan beberapa nomenklatur peran politik dalam rangka bertahan dalam konstelasi politik yang berubah. Untuk tantangan ini, makalah ini berpendapat bahwa pesantren perlu mendefinisikan dan memperluas mandat dewasa ini sebagai "broker politik" menjadi salah satu dari tiga nomenklatur berikut: (1) perumusan non-pemilihan politik; (2) redefinisi dari mandat ekonomi, dan (3) mengembangkan sistem teologi-politik.
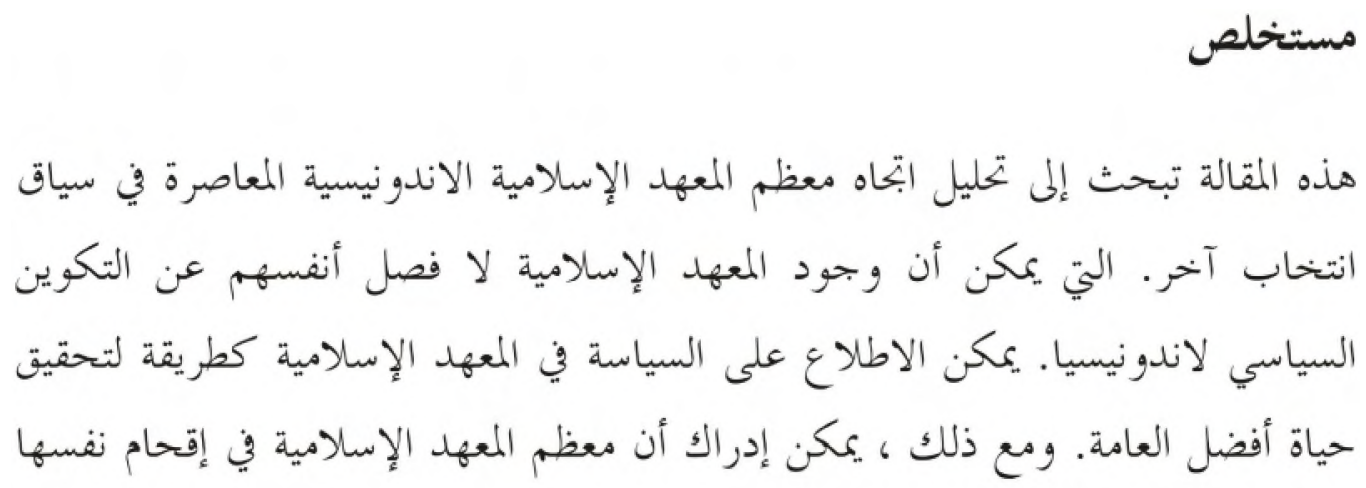

1 Translated and revised version of this paper was delivered in the seminar entitled "Peran Pesantren Pasca-Pilpres" (The Role of Pesantren in post-Presidential Elections" at Hotel Jayakarta, Jogjakarta, 10 August 2009 held by Ministry of Communication and Information of the Republic of Indonesia. 


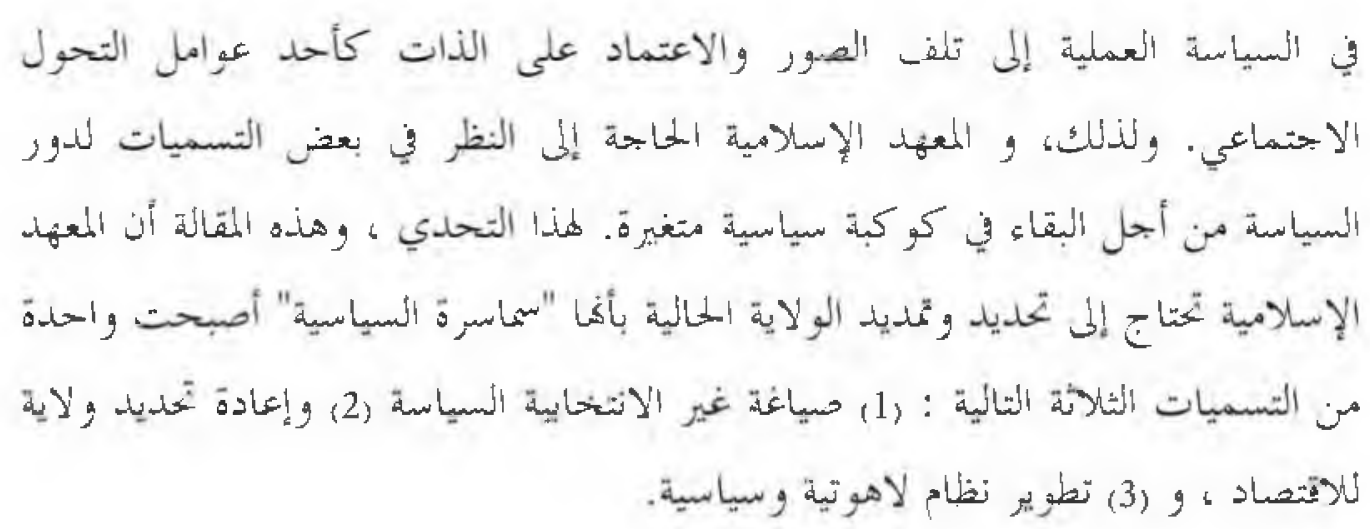

Keywords: Pesantren, Nomenclature, Non-electoral Politics, Economic Mandate, Theology of Politics

\section{A. Introduction}

The world of pesantren always receives high profile coveraged by the press following, during and after political events being held in Indonesia, such as legislative and executive elections, both at regional and national level. This is particularly due to the fact that pesantren is regarded unable to stay neutral amidst the configuration of political interests. Like a charming and attractive beautiful girl, pesantren suddenly becomes a new idol that attracts a great number of boys. In short, pesantren is tempted to plunge itself within "forbidden affairs" and "illegal political transaction" that leads to conflict of interests. Pesantren immerses itself in, for instance, a real political contest by supporting particular political party or running candidate during elections. As a result, pesantren has been widely claimed no longer able to maintain its prophetic role as the front-liner and defender of public morality. Pesantren has further become the agent of political power that seeks short-term pragmatic interests.

The above condition undoubtedly becomes the latest paradox of pesantren. It has to be admitted that since the outset, pesantren has championed the hearts and minds of wider community through a long process of social and religious transformation. It has without doubt contributed to the making of moderate Islam, playing its role -following the phrase of our first Indonesia's vice-president, Mohammad Hatta- as the "politics of salt" instead of the "politics of lipstick". The values of pesantren have coloured public morality that permeate the life of formal state structure. This paradox has degraded the image of Indonesia's pesantren which enjoyed its long reputation as being immune to political infiltration and 
temptation. All of this leads to a conclusion: the reputation of pesantren is now at stake nowadays that invites serious reflection among all elements of the society. A productive solution must be attempted in order to save the pesantren from more destructive effect of political temptation.

The questions would be; what is wrong with the pesantren? is there anything wrong with the involvement of pesantren in the real politics with the argument "to safeguard" corrupted political life? isn't it so that, according Plato, in the beginning politics is all about nobility and morality and, hence, pesantren has moral responsibility to restore the nobility of and morality of real politics?

This paper seeks to analyse the liability of new nomenclatures of political role of pesantren in the era of open democracy based on a close observation on the involvement of this institution within the world of political power. The discussion will emphasize on the history of pesantren, the diversification of its socio-political roles as a result of modernization, the political decay among pesantren-based politicians, and the search for liable new nomenclatures of pesantren that can play its political role more elegantly without necessarily depending itself on any external agents.

\section{B. Pesantren: A Brief Historical Account}

A pesantren is usually run by a kyai (religious clerics/teacher) assisted by a number of his senior santri (students) or other family members. ${ }^{2}$ The pesantren forms an important part of the kyai's life, since it is a medium to expand his preaching and influence over the society. In the pesantren system, there are several interconnected elements. The first is the kyai, the person who underpins the system. Secondly, there are the santri, the students who learn Islamic knowledge from the kyai. This element is also of great importance, since without the santri the kyai would be like a king without populace. The santri are human resources, who not only support the existence of the pesantren but also sustain kyai influence in society. It is nonetheless common nowadays that some kyai have neither santri nor pesantren.

2 For further information about pesantren, see, Zamakhsyari Dhofier, Tradisi Pesantren: Studi Pandangan Hidup Kyai (Jakarta: LP3ES, 1982); cf. Abdurrahman Mas'ud, Intelektual Pesantren: Perhelatan Agama dan Tradisi (Yogyakarta: LKiS, 2004); Cf. Dawam Rahardjo, Pergulatan Dunia Pesantren: Membangun dari Bawah (Jakarta: LP3ES, 1985); Cf. Manfred Ziemek, Pesantren dan Perubahan Sosial(Jakarta: LP3ES, 1986); Mastuhu, Dinamika Sistem Pendidikan Pesantren (Jakarta: INIS, 1994). 
The third element is the pondok, a dormitory system provided by the kyai to accommodate his students. Pondok is usually a simple form of accommodation and has fewer facilities than halls or colleges in Western universities. ${ }^{3}$

So far we do not have a reliable source that tells the historical root of pesantren. We do not even know when this institution came into existence for the first time. A great deal of information is given to the initial life of pesantren in its early phase, but represents merely as an extrapolation of the experience of pesantren in the late $19^{\text {th }}$ century. Pigeaud and de Graaf-as quoted by Martin van Bruinessenassert that pesantren serves as the second most important centre of Islamic studies, in addition to the mosque, during the period of early $16^{\text {th }}$ century. They assume that pesantren constitutes an independent realm that alienates itself from worldly affairs and is situated far from the public life such as mountainous area, derived its existence from pre-Islamic institutions such as mandala and asyrama. ${ }^{4}$ It is indicated that during the early stage of Islamization in Java, some pre-Islamic institutions survived; even new institutions were established. It is unclear, however, whether these centres served as the institution of textual learning. Therefore, van Bruinessen questions the existence of pesantren during the early stage of Islamization of Java. He assumes that this institution has been established lately as soon as Islam found its established base within the Javanese public life.

Some scholars tend to argue that the village of perdikan as a continuum of religious pre-Islamic institution. The village of perdikan, which was exempted from the tax and forced labour but the income must be spent for sacred duties such venerated graveyard, represents an old institution, and some perdikan villages in the $19^{\text {th }}$ century have enjoyed their status since pre-Islamic phase. Nevertheless, the existence of pesantren in a particular perdikan village does not have anything to do with its status of tax exemption. Based on the last survey in the late $19^{\text {th }}$ century, from 211 perdikan village there were only four villages that part of their income was used to take care of pesantren. ${ }^{5}$ The common reason to exempt tax from villages is the existence of holy graveyards. Furthermore, local kingdoms can bestow a perdikan status to particular villages surround them.

3 Endang Turmudi, Struggling for the Umma: Changing Leadership of Kyai in Jombang, East Java (Canberra: ANU E Press, 2006), 26.

4 Martin van Bruinessen, Kitab Kuning: Pesantren dan Tarekat Tradisi-tradisi Islam di Indonesia (Bandung: Mizan, 1995), 23-24.

5 Ibid. 
Popular sources about pesantren usually refer to the period of the nine saints (Walisanga) -despite the unavailability of reliable evidence- which is most often said to be the time when pesantren began to exist. While some historians in Indonesia refer to Maulana Malik Ibrahim as the founder of pesantren in Java, some others mention Sunan Ampel or Raden Rakhmat that built pesantren for the first time in Kembang Kuning Surabaya. ${ }^{6}$ In addition to Sunan Ampel, there are also other sources that refer to Sunan Gunung Djati who established pesantren for the first time during his isolation with his followers to a remote area in West Java. ${ }^{7}$ Despite all of this, no historical evidence so far can support the existence of pesantren. The first survey undertaken by the Dutch in 1819 on education for the native Javanese implies that the real pesantren had not yet been existed all across Java. Religious institutions similar to pesantren were reported to have existed in several parts of Java such as in Priangan, pekalongan, Rembang, Kedu, Surabaya, Madiun and Ponorogo. During that period, Madiun and Ponorogo were reported to have had the best pesantren educational system. ${ }^{8}$

As far as historical records are concerned, the oldest pesantren in Java that of Tegalsari in Ponorogo which was founded in 1742. ${ }^{9}$ There was no historical evidence whatsoever to indicate the existence of any pesantren in Java prior to that of Tegalsari. ${ }^{10}$ This pesantren was said to have had no more than 2,000 students from all across Java. Based on the census undertaken by the Dutch in 1885, from the total number of 15,000 religious schools in Java, with 230,000 students, there were no more than about 200 pesantrens in Java that taught more than elementary Islam such as the study of Islamic law, theology and other advanced topics. ${ }^{11}$ During that time, it was almost universal for young Javanese males to spend some time in pesantrens. These institutions were welcomed to almost anybody who sought religious sciences, even it is reported that the poorest could attend a pesantren, living on alms. ${ }^{12}$ The pesantrens thus served as the social hub among young Javanese men from across Java.

6 See, for instance, Mahmud Yunus, Sejarah Pendidikan Islam di Indonesia (Jakarta: Hidakarya Agung, 1985), 231; Cf. Soeparlan Soeryopratondo and M. Syarif, Kapita Selekta Pondok Pesantren (Jakarta: PT Paryu Barokah, n.d.), 6; Cf. Mujamil Qomar, Pesantren: Dari Transformasi Metodologis Menuju Demokratisasi Institusi (Jakarta: Erlangga, 2008), 8.

7 See, for instance, Machrus Aly, "Hakekat Cita Pondok Pesantren," in Soeparlan Suryopratondo and M. Syarif, Kapita Selekta Pendidikan, 40.

8 Van Bruinessen, Kitab Kuning, 25.

9 Ibid.

10 Ibid.

11 M.C. Ricklefs, Polarising Javanese Society (Singapore: NUS Press, 2007), 70.

12 Ibid. 
There is no definite record as to how many pesantrens are there in Indonesia. Popular sources mention that the total number of pesantrens in this country exceeds $14,000 .{ }^{13}$ According to formal release by Ministry of Religious Affairs of the Republic of Indonesia, the number of pesantrens in this country exceeds 21,521 with their various types of learning and characteristics. ${ }^{14}$ Those pesantrens usually comprise sub-educational formal institutions at various levels from kinder garden to higher education. This is a result of a long process of transformation since the second half of the $20^{\text {th }}$ century. The pesantren system encompasses the backbone of NU affiliatededucational system, even though other social organizations also such as Muhammadiyah and Persis have the same system. ${ }^{15}$

\section{Diversification of Pesantren's Socio-Political Role}

The existence of pesantren, since its inception in Java, could not be disassociated from the existing social structure of agricultural community. This is simply because this institution was developed from agriculture based society. As a consequence, the pesantren community places one of the chains of the web and structure of agricultural society which, in turn, forms its own mode of production. The pesantren community, thus, has been embedded to the non-state entrepreneurship culture, where its mode of production could sustain its survival. The endurance and sustainability of pesantren was attributed to its mode of production and not to external factors such as political support from the local political institutions and figures.

Nevertheless, modernization process leads to unprecedented changes at the level of social structure of pesantren. The agricultural culture as the backbone of pesantren's mode of production has been eroded by new industrial culture that requires soft-skills that are totally different from agricultural culture. Modernization

13 Greg Barton, "Jemaah Islamiyah Terrorism and Radical Islamism in Indonesia," in Shahram Akbarzadeh \& Samina Yasmeen, Islam and the West: Reflections from Australia (Sydney, UNSW Press, 2005), 126. See, also, ICG, Jemaah Islamiyah in Southeast Asia: Damaged but Still Dangerous, ICG Asia Report No. 63 (26 Ausgust 2003), 26-27.

14 Ministry of Religious Affairs of the Republic of Indonesia (http://www.indonesia.go.id), accessed 3 July 2011.

15 Peter Clarke and Peter Beyer (Eds.), The World's Religions: Continuities and Transformation (New York: Routledge, 2009), 311. See, also, Martin van Bruinessen, "Traditionalist and Islamist Pesantrens in Contemporary Indonesia”, in Ahmad-Noor, et. Al. (Eds.), The Madrasa in Asia: Political Activism and Transnational Linkages (Amsterdam: Amsterdam University Press, 2008), 217-246. 
process has altered the configuration of social roles played by social units and has forced them to adapt to the changing condition. ${ }^{16} \mathrm{~A}$ further consequence of the alteration of social structure is that the "field" of pesantren has been narrowed following the expansion of modernization and industrialization process. The character alteration of the community from agricultural culture to industrial culture has forced pesantren to redefine their social roles. Therefore, the diversification in social role of pesantren is an unavoidable consequence in order for the pesantren to be able to adapt their selves to the need of modernization.

It is obvious that the process of modernization bring unprecedented consequences of the erosion of pesantren's old roles on the one hand and the introduction of their new roles on the other in order to maintain their survival and continuity. Such an adaptation constitutes the hardest stage the pesantren's community must experience, where they have to disassociate old attributes as their historical legacy as well as their main backbone to their continuity. The pesantren's community do not have other options except taking anticipative measures in order to adapt themselves with their social demands and new roles.

Modernization has not only brought about the alterations of pesantren's social roles, but also the pesantren's movements amidst the socio-political dynamics of the more open world. At the level of political structure, modernization has offered some new nuances that can stagger the established configuration of political order. In this context, modernization can be depicted as "dawn raids" over the existing political structure, to be replaced by more relevant new socio-political structure. It is within this context, as a part of the dynamics of socio-politics, pesantren form an integral part of such a process of political transformation. Whether like or dislike, pesantren is forced to face up with the changing socio-political structure as a result of that modernization waves.

By means of those democratization waves, new values started to be introduced into the community, such as democracy, civic liberty, human rights, gender equality, and the like. Such values are a clear challenge that must be responded by the pesantren in order to maintain their vitality among the ever-changing society. This leads to the beginning of pesantren empowerment and development projects in order to keep their pace to those modern issues. Among the Indonesia's pesantrens, the movement of new awareness to the new values started to spring out since the 1980's,

${ }_{16}$ Marion Joseph Levy, Modernization and the Structure of Societies: Aspects of Social Structure in Modernized and Non-modernized Societies (New Jersey: Transaction Publishers, 1996), 87. 
when this institution started to keep their distance from the real political sphere. There has been a great deal of pesantrens that served themselves as a crisis centre to undertake advocacy of those new values to the wider community. As a consequence, the pesantren community has abruptly become new icon of empowerment programs based on those values.

Quoting Samuel Huntington, "Modernization means mass mobilization; mass mobilization means increased political participation; and increased participation is the key element of political development". ${ }^{17}$ In support of the above Huntington's thesis, Almond and Verba also emphasize the significance of political participation in public sphere. They argue that

"The new world political culture will be a political culture of participation. If there is a political revolution going on throughout the world, it is what might be called the participation explosion. In all the nations of the world the belief that the ordinary man is politically relevant-that he ought to be an involved participant in the political system-is widespread. Large group of people who have been outside politics are demanding entrance into the political system." 18

Following the above theoretical construct, the involvement of pesantren in a real political sphere can be understood positively as a concern of pesantren towards the restoration or the betterment of community's political life as a whole. The simple formula is that the involvement of pesantren in the public sphere, especially in the real political sphere, can show its positive contribution to the development of the nation's politics. The assumption is that, the figure kyai/ santrican play their roles as the transformer of the dynamics of community's participation in democratization process, and this is a good indication for the socio-political participation of pesantren.

Since the collapse of the New Order regime, pesantren has been socially and politically active in the public sphere. The introduction of Reformasi era has allowed an unprecedented phase where all elements of the society were given an equal chance to take part in making what constitutes the common good for the country. ${ }^{19}$ This is the period where democracy has become the single rule of the game for all. This is

17 Samuel Huntington, "Political Development and Political Decay," World Politics, Vol. 17, No. 3 (April 1965), 388.

18 Gabriel A. Almond and Sidney Verba, The Civic Culture (Princeton: Princeton University Press, 1963), 3.

19 Masdar Hilmy, Islamism and Democracy in Indonesia: Piety and Pragmatism (Singapore: ISEAS, 2010), 62; Cf. Arief Budiman, Barbara Hatley and Damien Kingsbury (eds.). Reformasi: Crises and Change in Indonesia (Melbourne: Monash Asia Institute, 1999). 
the period where democracy has finally championed over Suharto's totalitarian regime. This wave of democratization, however, serves as a doubled edge sword; on the one hand it paved the way for the betterment of the society through political participation for all which has never been the case beforehand. The regime shift benefitted the world of pesantren as a whole. The democracy era, where popularity becomes the hallmark of any political game at stage, has given huge opportunity for the pesantren community to take an active role in politics. As it happened during the liberal democracy in the Soekarno's regime, ${ }^{20}$ this democracy era signifies the return of the "lost world" for pesantren, i.e. the real politics.

The democracy era, however, has never always been welcomed by the pesantren community with their well-preparedness. This is precisely the crux of the "problem" of the pesantren community in democracy era. By and large, the world of pesantren has not managed to play in the arena of democracy in a more elegant manner due to its unpreparedness. Democracy has different features where political soft skills are urgently needed by any individual who wish to compete in the democracy game. As a result, democracy wave in Indonesia seems to be a shocking phenomenon for the pesantren rather than a real blessing. Through Abdurrahman Wahid-led Partai Kebangkitan Bangsa (PKB), the pesantren community had to face a totally different world as they have been through beforehand, i.e. the fierce competition of the world of politics. This condition has forced pesantren to have had an abrupt shift in their paradigm from "non-interventionist" paradigm into an "interventionist" one in politics. Any shift in paradigm always results in a suffering, as it was the case for the world of pesantren. This is because the "interventionist" paradigm of political participation is a situation where the pesantren has never imagined in advance.

In short, the pesantren's involvement in politics has not yet accompanied by a well organized plan and blue-print as to how the pesantren values can guide individuals to behave properly and correctly. In this case, the victory of PKB under Abdurrahman Wahid (Gus Dur) cannot be regarded as the representation of the pesantren's victory in the world of politics. PKB during the early phase of Reformasi era was the only political party that explicitly channelled the aspiration and interest of pesantren. This early phase was characterized by the solid and relatively cohesive attitude of the pesantren kyais which could direct the political behaviour of their followers among santris and the pesantren community at large. This is the phase

20 Robin Bush, Nahdlatul Ulama and the Struggle for Power within Islam and Politics in Indonesia (Singapore: ISEAS, 2009), 56. 
where the successful stories of the pesantren community begin. The direct election system has benefited the community of pesantren because the kyais and family as well as any individual closely associated with pesantren can be politically more competitive as it never been so in the previous era. Any individual of the pesantren can be elected thanks to popularity modality among his/her society.

There have been several patterns of the pesantren's involvement in the real politics. The first pattern is where the pesantren is involved in political transaction to support any politician who runs his/her candidacy as a governor, head of district, parliament member and the like. This is done by utilizing pesantren's modalities to mobilize political support for a particular individual. In a community where the pesantren can exercise its influence over the society, the political support from the kyais and their family becomes crucial for anyone to take into account if he/she wishes to run in a political contest. The second pattern is when the community of pesantren such as the kyais and santris go themselves into the contest. There are of course various motives behind the direct involvement of the pesantren community in politics. One of them is moral reason: they wish to restore the condition of the society in order to experience a better life. This is why it is not surprising that a lot of kyais or pesantren based individuals were successfully elected during elections, either at legislative elections or executive ones.

The episode of pesantren's adventure in the real politics begins with the stories of successful kyais, santris or pesantren-based individuals on the political stage. These stories are appreciated joyfully by the pesantren community as a good beginning. This is mainly characterized by vertical mobility of kyai/santri into the pyramid of politics and power, starting from district level, provincial, up to national level. The peak of pesantren's achievement might be well represented by the ascendancy of Gus Dur as the forth President of the Republic of Indonesia, a never unprecedented political experience of pesantren since the founding of this Republic.

The ascendancy of Gus Dur into the political pyramid later on stimulated other pesantren based community to join his step in the real political stage. ${ }^{21}$ The phenomenon of the kyais or gus's (the son of kyais) involvement in politics becomes a common thing to notice. From that time on, the community of pesantrens seem

21 See, for instance, Zuly Qodir, "Gus Dur, NU, dan Perjuangan "Civil Islam", in Gus Dur, Santri Par Excellence: Teladan Sang Guru Bangsa (Jakarta: Penerbit Buku Kompas, 2010), 287; Cf. A. Malik Haramain, Gus Dur, Militer, dan Politik (Yogyakarta: LKiS, 2004). 
to have a political charm for those who wish to run their candidacy by inviting anyone who has anything related to pesantren. One can notice as to how the kyais become a new icon for politics if one wants to become a formal political leader. If not the kyai himself who wanted to run for candidacy, one should have the kyais' consent to run into election. Considering all of this, it is no wonder that the ascendancy of kyais or santris can be regarded as the ascendancy of pesantren in the world of politics.

The 2004 national election, for instance, was marked by the involvement of some kyais of the pesantren in the national election for presidency. $\mathrm{KH} \mathrm{Hasyim}$ Muzadi-as the general Chairman of NU-was in tandem with Megawati Soekarnoputri and Shalahuddin Wahid-the head of pesantren Tebuireng in Jombang-was in tandem with Wiranto. ${ }^{22}$ In reality, both proved to have failed and lost to the pair Susilo Bambang Yudhoyono-Jusuf Kalla. In addition to executive elections, the legislative elections have been also crowded by pesantren-based politicians. The parliamentary buildings all across the country-from the national, provincial to district and municipality level-have been crammed with pesantrenbased politicians that are spread out in several political parties, both Islamic and "secular" political parties.

The successful stories of pesantren-based politicians are of course amazing. This is because the world of pesantren has been marginalized from the sphere of politics by the previous regimes, especially during the New Order period. Those successful stories above, however, are not long-lasting when other side of unsuccessful stories of the pesantren-based politicians were exposed. This is due in part to the failure of those politicians in performing on good and clean governance standard. In reality, the majority of those politicians were not well-armed with soft-skills that are required by the mechanism of politics. Some of them are even involved in moral scandals such as corruption and some of these people have been taken to jail. The major problem faced by the pesantren-based politicians is the lack of political skill and communication need in a real battle or contest. This fact results in frequent failures experienced by pesantren-based politicians in many political contests. These

22 Ign.Ismanto, et. Al., Pemilihan Presiden Secara Langsung 2004: Dokumentasi, Analisis dan Kritik (Yogyakarta: Penerbit Galang in collaboration with Kementerian Riset and Teknologi dan Departemen Politik dan Perubahan Sosial CSIS, 2004), 68. See, also, Khoirudin, Kilas balik Pemilihan Presiden 2004: evaluasi pelaksanaan, hasil, dan masa depan demokrasi pasca pilpres (Yogyakarta: Pustaka Pelajar, 2004). 
unsuccessful stories seem to highlight the reality that they are not fully ready with moral requirements needed by governance standard.

The root cause of those failures can be traced back to many factors, the important of which are; first, the unavailability of blue-print that lead and direct the political behaviour and performance of pesantren-based politicians. While the blue-print of political conduct is unavailable, the pesantren-based politicians are forced to plunge into the political stage with insufficient modalities. Second, it has to be admitted that these politicians are too dependant on modalities that are contingent upon individuals such as charisma and popularity of the kyai/santri. These features did not guarantee the successfulness of particular pesantren-based politicians in politics. This is so because political stage has some fundamental rationales that are totally different from the religious rationales the kyais/santris commonly have. In this case, popularity and charisma will not necessarily guarantee the better votes in politics. Both are different to one another. ${ }^{23}$ To this point, the pesantren community seems to face a culmination as a result of the erosion of the support from the society at large. In an extreme phrase, the pesantren authority has been undergoing a process of devaluation in politics even though in religious sphere it is not the case.

\section{Political Decay among Pesantren-based Politicians}

From the successful stories about the adventure of pesantren-based politicians above, it is obvious that not all of them find a happy or positive ending in the end. Not few of them even had to face a tragic story where they were finally taken to jail because of the corruption scandals. This almost signifies the end of their career in politics. This is not to mention the internal conflicts within pesantren-based political parties with higher intensity compared to those of non-pesantren-based political parties. In other words, all of those successful stories do not necessarily guarantee a happy ending for pesantren-based politicians. The involvement of pesantren in political sphere, therefore, did not make it better; on the contrary, it made it worse.

23 The decline of charisma of a leader signifies the end of traditional leadership pattern and the beginning of modern-rational leadership pattern in public sphere. In the Weberian theoretical construct, traditional leadership pattern is commonly characterized by the working of unbalanced patron-client relation pattern between the leaders and the led. The modern-rational leadership pattern in the era of democracy corrodes charismatic leadership pattern. For further explanation on Max Weber and charisma-based leadership, see, among others, Reinhard Bendix, Max Weber: an Intellectual Portrait (London \& New York: Routledge, 1998), 301-29. 
The pesantrens were even involved in the process of political decay in the society at large, a paradox situation. Why can all of this happen?

As mentioned above, one of the strong assumptions that is responsible for the failures of pesantren-based politicians in political life because this institution, by definition, has not had or provided a sufficient soft skill that can bolster the involvement of pesantren community in the fierce and brutal field of practical politics. As a result, the pesantren community tends to be drained within the mainstream of established political logics of the society. In reality, the pesantren values are still powerless in dealing with the corrupt mentality of the mainstream; the pesantren should have been able to play its role in enlightening morally the reality of practical politics and not drawn within the strong mainstream of corrupt political system. In Huntington's theoretical assumption, the pesantren has even contributed to the making of social and political decay of the society and state. ${ }^{24}$ It is within this context that pesantren has lacked its attacking ammunition to deconstruct the existing socio-political structure in order to be replaced by a new socio-political structure based on pesantren's moral values.

Second, our political system in general still cannot accommodate good and clean governance political system, so that it becomes unrealistic to point our finger blame at pesantren to be responsible to the decay of politics. Pesantren with its abundant value system can only serve as normative basis on the one hand, while the practical politics is a complex reality, on the other. Bringing the two different worlds together in one platform is not an easy task, due to the fact that each of them has its own framework and logic. Nevertheless, the contribution of pesantren can be made possible only if there are enough political actors with high moral integrity to internalize and objectify those moral values.

Third, there is a kind of deep institutional lag between pesantren as an educational institution and political system outside of pesantren. Borrowing Bourdieu, each of them has different, if not contradictory, habits. ${ }^{25}$ Pesantren is a breeding ground for cultivating religious morality from which ideal values are derived. On the other hand, political system is closely associated with disharmony, conflict, wickedness, public untruthfulness, and the like. As a consequence, like water and oil, both of them do not have modality of chemistry. The world of pesantren and

24 Huntington, "Political Development and Political Decay," 415-17.

25 Pierre Bourdieu, Outline of a Theory of Practice (Cambridge: Cambridge University Press, 1977), 78. 
political reality are often said to have destined unable to find a common denomination to live together side by side, a counterproductive ground for the existence of participatory democracy.

During the New Order and earlier, the connection of pesantren with politics was not that far, because many political actors were born and grown from the world of pesantren. ${ }^{26}$ During the post New Order period, when participatory democracy has been the only rule of the game in town, pesantren's popularity skyrocketed drastically; not in their capacity as the enlightening agent of the morality of real politics or politicians, but not more than a tempting vote-getter for all political entrepreneurs who wish to go into the convenience of worldly politics. As a result, without any invitation, those politicians will voluntarily come to pesantren for the kyais' consent or for political transaction with the pesantren community. The world of pesantren, in fact, in some parts of Java has enjoyed its high profile and the kyais are fully aware of this position.

In the past, especially during the New Order, pesantren has undergone a bitter political experience by the government. The pesantren community was frequently forced to accept the government's tacit invitation to join Golkar, the ruling party of the regime. This is why the NU-affiliated pesantrens were managed to an exit strategy by formulating the so-called Khittah NU, literally means the return to the basic identity of NU as a socio-religious organization. The popular analogy used to describe the agony of NU-affiliated pesantrens during that period is that the pesantren community was exploited to push a stalled car; but as soon as the car is running the pesantren community was left behind. This analogy is frequently used to describe the unfavourable condition of pesantren community which was only exploited by limited political elite for short-term political interests. This analogy also symbolizes the socio-economic-political deprivation and dislocation. The pesantren community, either kyais or santris, were often hauled by the rulers and politicians, only in particular context when needed. But as soon as the political interests were attained, the world of pesantren was neglected. The pesantren community did not receive any long-term advantages from those political transactions.

26 Like A. Wahid Hasyim, the father of Abdurrahman Wahid, a national hero who had been the member of BPUPKI and PPKI as well as the minister of religious affairs of the Republic of Indonesia. There was also Mahbub Djunaidi who had been the member of DPR Gotong Royong/ MPRS and the Chairman of Dewan Pimpinan Pusat (DPP) PPP, and still many others. 
Different from the previous era which was characterized by the totalitarian political system, the democracy political system allows the pesantrens involved in public sphere more widely. The pesantren needs to be able to define its proper role amidst the changing political system of the state. The role of pesantren within the existing political configuration constitutes within only one of following two patterns; first, pesantren as a vote-getting base for some politicians who are running their candidacy as executive or legislative leaders. Second, pesantren has provided with human resources to fill political posts, either at the executive or legislative level. Outside of those posts, the pesantren is unable to articulate its political role in accordance with the aspiration of the wider ummah. These posts, therefore, are hoped to be filled by the pesantren community in order to be able to keep its roles within the changing community.

\section{E. In Search for (a) New Nomenclature}

Taking into account all of the unsuccessful stories of pesantren on the political stage above, it seems that a new format of a more elegant political role of pesantren needs to be formulated. That new format for political role of pesantren is hoped to maximize the potencies of pesantren as a base for empowering the political culture of society through the adoption of good and clean governance principles. The formulation efforts will be finally designed to bridge the normative disparity between pesantren and the real practical politics.

In order to fulfil the need to redefine the political role of pesantren, there are at least three important nomenclatures that can be developed in the future, so that the pesantren community can maximize its empowering and enabling function in the process of socio-political transformation of the country.

1) Non-Electoral Politics

The pesantren community has been deemed politically unsuccessful in the political stage because of its blatant involvement in political transaction. The action of lending support to particular candidates by the pesantren community during general or regional elections, for instance, represents the involvement of pesantren in those electoral elections. This has been accompanied by the fact that some pesantren based politicians have been accused to be involved in money politics. The underlying paradigm behind those types of involvement is "who gets what," and not "who does what." As a consequence, pesantren has been widely stereotyped as the seekers of short-term economic-political profits, a counterproductive image to the cultivation of the pesantren's prophetic roles in the future. 
Indeed, there is nothing wrong with the involvement of pesantren in the practical politics, especially when the main motive behind that involvement is to restore the public morality. This way, however, risks too expensive for the pesantren. The repeated losses indicate the unpreparedness of pesantren's soft skills in facing the era of open political democracy. If it is unsolved, this reality can devaluate the image of pesantren as "political broker" that undermines its prophetic function as the guardian of public morality. Let alone when the pesantren-based individuals prove to be directly involved in pioneering the process of political decay in the society. If this is the case, it is worried that the image of pesantren will be demoralized in the eyes of society at large.

It has to be admitted that the pesantren is deemed successful when it was able to play its non-electoral politics as-borrowing Geertz-"cultural brokers". ${ }^{27}$ By cultural brokers it does not mean that pesantren is politically illiterate. This is because the distance of pesantren from the reality of practical politics can improve its bargaining power vis-a-vis the state. The role of non-electoral politics played by pesantren seems to be more elegant and well-esteemed rather than electoral politics which quite often undermine the authority of pesantren. There a lot of things can be done through such a thread, by the empowerment and advocacy of marginalized community. A further consequence of this is that there will be emotional tie between the marginalized community and the world of pesantren as a crises centre. This reality can be the pesantren's invaluable long-term cultural modality and infestation instead of short-term political-economical interests.

The strengthening of community-based politics was carried out through advocacies and affirmative action on marginalized communities. Pesantren has emerged as a balancing power that supported civil society in relation to the relation between the community and the state. During the New Order, the pesantren was dominant as a civil society through community empowerment programs supported by P3M (Perhimpunan Pengembangan Pesantren dan Masyarakat) and LP3ES (Lembaga Pendidikan, Pengkajian dan Penerapan Ekonomi dan Sosial). ${ }^{28}$

In short, by means of non-electoral politics pesantren gets back to its "barrack" (khittah, prophetic role) as an enlightening agent of ummah morality. Pesantren

27 Clifford Geertz, "The Javanese Kijaji: The Changing Role of a Cultural Broker," Comparative Studies in Society and History, 2 (1960), 228-49.

28 Martin van Bruinessen, NU Tradisi Relasi-relasi Kuasa: Pencarian Wacana Baru(Jogjakarta: LKiS, 2008), 213-33. 
has to be back to the commitment of serving to the wider community to provide with the optimum service in the field of religious education as it has been shown so far. Such a non-electoral politics proves to have made the pesantren as a great and well-respected educational entity in the process of social transformation. But when it is immersed more deeply into the electoral politics, its audience were neglected because their patrons looked into something out of their main duty.

2) Expanding "the Mandate of Economy"

To take the pesantren back to its original place, however, is not an easy job. This is because -as described earlier-modernization has created the diversification process of pesantren's social roles from "cultural brokers" (mainly as the provider of community needs in religious services) to "political brokers" (in terms of transactional politics during elections). Furthermore, the modernization has narrowed the pesantren's room of manoeuvre in creating its "buffer zone" for its survival. Pushing pesantren into the world it does not belong to, i.e. politics in its wider sense means that the rights of pesantren have been curtailed. Politics is something already embedded since its birth. The existence of pesantren so far is the existence of its champion in politics par excellence. How can we divorce something that is already embedded since its birth?

It is from this point of departure that a new breakthrough is urgently needed by the pesantren, by among others, expanding its "economic mandate", not only as the "cultural brokers," but also "economic brokers" in its wider sense. The pesantren needs to emphasize more on economic works in order to strengthen its "buffer zone". Entrepreneurship education and apprenticeships for santris in the field of economy-industry, and the networks of pesantren with the industrial world can be main requirement for the expansion of pesantren's "economic mandate".

The expansion of economic mandate is not really a new thing for pesantren. Pesantren-based mode of economic production has been widely undertaken, but still limited to few pesantrens. Pesantren Sidogiri in Pasuruan, Gontor in Ponorogo, Azzaitun in Indramayu, Darut Tauhid in Bandung, the farming pesantren of "Darul Falah" in Bogor are but few examples of successful pesantrens that to some degree have been successful in moving pesantren's economic mode of production. But in general, economic works done by pesantren were undertaken partially, and not in the level of wider economic networking between pesantrens that can contribute to the creation of good bargaining power for economic institutions outside of pesantren. In addition, the pesantren's economic mode of production is done for itself, not the economy for wider community. 
NU and the pesantren community in the early 1990s has pioneered empowerment programs to improve the capacity of economic life of society by founding Bank Perkreditan Rakyat (BPR, People Loan Bank) NU which provided small-scale loan for small NU-based entrepreneurs and farmers. ${ }^{29}$ These BPRs were not free-interest banks, like non-usury Islamic banks, but conventional banks that drew interest rate from their customers. BPR-NU was firstly founded in Sidoarjo in March 1990. This constituted a joint-venture between NU and Chinese Muslims who contributed the biggest share and their managerial skills.

In June 1990, NU signed a Memorandum of Understanding (MoU) with Bank Summa (belonged to Astranya William Soerjadjaja) to establish more Bank Perkreditan Rakyat. With the name Nusumma, acronym of NU and Summa, the new banks benefited NU and its community a lot. Bank Summa was willing to provide the first capital and dealing with training for NU affiliated individuals in order to have apprenticeship and then becoming the permanent staffs of BPR. Nusumma thus was not only advantageous for NU community who needed loan, but also played crucial roles through transfer proses of soft-skills of banking management system to wider community. Since early of its inception, NU would hold the management of Nusumma, and the Summa's share would be reduced gradually..$^{30}$

The number of BPR which was established by Nusumma was only 9, with small initial capital of $\mathrm{Rp} 250$ million in each. This effort was, nevertheless, can be regarded successful as economic incentives which proved to be stimulating not only the economy of pesantren community, but also the economy of lay community at large. After two years since its inception, four of them have produced profit while the other three have reached break event point. Bank Summa at that time was claimed bankrupt due to debt particularly when the Bank Central decided no longer supported it. Liquidation of Bank Summa forced Soerjadjaja to sell most of his assets in Astra. More surprisingly, however, Nusumma remained to survive thanks to the support given by Jawa Pos group in Surabaya that bought Summa's share in Nusumma.

3) Developing a Theology of Politics

The last nomenclature of pesantren which is also of relevance to ponder is by formulating a blue-print of theology of politics to which the community of pesantren

$\begin{array}{ll}29 & \text { Ibid., } 230 . \\ 30 & \text { Ibid., } 232 .\end{array}$ 
and wider community can refer. It has to be admitted that the existence of pesantren has been so far under the hegemony of the corrupt political mainstream because it has not had an established blue-print of theology of politics which can be disseminated widely to the community at large. Within the social structure where pesantren serves as one of the important pillars, the existence of pesantren alumni /santri in practical political sphere should have provided enough "theological ammunition" for transplanting good moral values. In reality, however, the pesantren community has been coopted, instead of coopting, the logic of corrupt political norms widespread in the society. This condition must be of the pesantren concerns if it wishes to maintain its significance in the society.

The lack of the formulation of pesantren's political theology has concerned Ali Haidar. ${ }^{31}$ The reference to classical books as an intellectual product of Middle Age period without any adequate contextualization to the changing era of today has contributed to the lack of pesantren alternatives to adopt the relevant formula of political theology. In addition, this reality is deteriorated by the founding of pesantren-based political parties which was not well-equipped with an adequate blue-print of politics. As a result, those political parties tended to exploit religious symbols excessively which is not the real demand of the society. The society's need such as poverty eradication, unemployment reduction, the improvement of quality of education, was not met by the pesantren.

It is even more challenging when talking about the current issues of complex state structure. The formulation of pesantren's classical political theology will not be able to accommodate the complexity of that structure, unless new endeavour is achieved to reformulate the blue-print of pesantren's political theology in a more applicable code of conducts. The old formulation, most of which is based on ushuliyah principles, might be relevant only to particular age and place. The Old Order and New Order have served as laboratory for the experimentation of pesantren's political theology, with some significant breakthroughs in the arena of nation-state politics. ${ }^{32}$

Maintaining such a formula within the context of today's state structure, however, needs to be reformulated in order to suit perfectly with the most current

31 Ali Haidar, "Dilema Warga Negara dalam Tradisi NU," in Mohammad AS. Hikam, et. al., Fiqh Kewarganegaraan, Intervensi Agama-agama terhadap Masyarakat Sipil(Jakarta: PB PMII, 2000), 107-114.

32 Laode Ida, NU Muda: Kaum Progresif dan Sekularisme Baru (Jakarta: Erlangga, 2004), 152. 
demands. This is only to preserve the pesantren's relevance to the existing political configuration. State structure needs the adoption and application of good and clean governance, a political paradigm that was nonexistent during the previous era, either during the Old Order and New Order. Pesantren, therefore, must be ready to pioneer the reformulation effort a good and clean governance-based system of political theology. By doing so, pesantren is hoped to remain updated with the contemporary challenges and needs of the state and community in general.

The formulation of pesantren's blue-print of political theology is not something difficult to realize. A collaborative effort between pesantren and educational as well as political institutions outside of it is likely to achieve a more progressive blueprint of political theology. The availability of pesantren's alumni spread-out in various strategic posts both in legislative institution and executive one represents an institutional modality that can be utilized as a networking basis in formulating pesantren's political theology. Pesantren proves to be the productive provider of successful politicians and statesmen, but also intellectual and religious leaders who have been active in the world of intellectualism in Indonesia. These both sides, pesantren alumni spread-out in various posts on the one hand and intellectualreligious leaders on the other hand, can be hand in hand in an intellectual enterprise in formulating pesantren's blue-print of political theology.

The role as the provider of blue-print of political theology is urgently needed through the following steps: first, the formulation of pesantren curriculum which is of relevance with the needs of the society. This can be done, for instance, by integrating the classical Islamic books with new political discourses being developed by the society. Second, pesantren can provide a service of political literacy for new and young politicians or candidate of politicians who wish to take part an active role in politics by means of the curriculum of political theology formulated by the pesantren. By doing so, pesantren has played its political role in an elegant manner, by not involving itself in the epicentre political conflict of interests, but serving as the enlightener of public morality as a whole.

\section{F. Concluding Remarks}

Undermining the political logic of pesantren means to divorce two sides of the same coin. This is so because this institution is politically active since its birth. Furthermore, pesantren is itself a political institution par excellence, resulting from a long episode of political battle between Islam as an entity on the one hand and external 
powers such as local beliefs and other types of crimes on the other. It is not an exaggeration, therefore, to argue that the existence of pesantren symbolizes the victory of kyai with his followers against its opponents within long-term socio-political contests. Pesantren, thus, represents the victory of Islamic values over other external ones.

Within that long time span since its birth, pesantren proves to have been able to preserve its relevance to the community's needs because this institution has been able to contribute to the betterment of the quality of public life, especially in religious matters. The modernization waves, however, have threatened the existence of pesantren as a long-lasting classical Islamic education system. The endurance and survival of pesantren towards the invasion of changes is attributed to the strength of its buffer zone, that is, its traditional-agricultural roles. In the future, however, such a buffer zone is doubted to be relied upon due to the fact that modernization has shaken the pesantren's structure of socio-economic-political relations.

Modernization resulting in diversification process of socio-political roles of pesantren is something one cannot deny. In response to that, pesantren should take immediate measures if it wishes to maintain its prophetic role. The above three nomenclatures are only an initial formulation that needs to be critically examined further prior to being adopted in pesantren. The three are not panacea either, because their curative strength will be dependant upon the condition and uniqueness of each pesantren. Pesantren can take one of the three or all of them altogether, with the hope that pesantren can restore its relevance and vitality as the agent of public morality on the basis of its own standing and not dependant upon external factors outside of it.

\section{BIBLIOGRAPHY}

Almond, Gabriel A. and Sidney Verba. 1963. The Civic Culture. Princeton: Princeton University Press.

Greg Barton. 2005. "Jemaah Islamiyah Terrorism and Radical Islamism in Indonesia," in Shahram Akbarzadeh \& Samina Yasmeen, Islam and the West: Reflections from Australia (Sydney, UNSW Press.

Bendix, Reinhard. 1998. Max Weber: an Intellectual Portrait. London \& New York: Routledge.

Bourdieu, Pierre. 1977. Outline of a Theory f Practice. Cambridge: Cambridge University Press. 
Budiman, Arief. 1999. Barbara Hatley and Damien Kingsbury (eds.). Reformasi: Crises and Change in Indonesia (Melbourne: Monash Asia Institute.

Bush, Robin. 2009. Nahdlatul Ulama and the Struggle for Power within Islam and Politics in Indonesia. Singapore: ISEAS.

Clarke, Peter and Peter Beyer (Eds.). 2009. The World's Religions: Continuities and Transformation (New York: Routledge.

Dhofier, Zamakhsyari. 1982. Tradisi Pesantren: Studi Pandangan Hidup Kyai. Jakarta: LP3ES.

Geertz, Clifford. 1960. "The Javanese Kijaji: The Changing Role of a Cultural Broker," Comparative Studies in Society and History, 2.

Haidar, Ali. 2000. "Dilema Warga Negara dalam Tradisi NU," dalam Mohammad AS. Hikam, dkk., Fiqh Kewarganegaraan, Intervensi Agama-agama terhadap Masyarakat Sipil. Jakarta: PB PMII.

Hilmy, Masdar. 2010. Islamism and Democracy in Indonesia: Piety and Pragmatism. Singapore: ISEAS.

Haramain, A. Malik. 2004. Gus Dur, Militer, dan Politik. Yogyakarta: LKiS.

Huntington, Samuel P. 1965. "Political Development and Political Decay," World Politics, Vol. 17, No. 3. April.

ICG. 2003. Jemaah Islamiyah in Southeast Asia: Damaged but Still Dangerous, ICG Asia Report No. 63.26 Ausgust.

Ida, Laode. 2004. NU Muda: Kaum Progresif dan Sekularisme Baru. Jakarta: Erlangga, 2004.

Ismanto, Ign. et. al. 2004. Pemilihan Presiden Secara Langsung 2004: Dokumentasi, Analisis dan Kritik Yogyakarta: Penerbit Galang in collaboration with Kementerian Riset and Teknologi dan Departemen Politik dan Perubahan Sosial CSIS.

Joseph-Levy, Marion. 1996. Modernization and the Structure of Societies: Aspects of Social Structure in Modernized and Non-modernized Societies. New Jersey: Transaction Publishers.

Khoirudin. 2004. Kilas balik Pemilihan Presiden 2004: evaluasi pelaksanaan, hasil, dan masa depan demokrasi pasca pilpres. Yogyakarta: Pustaka Pelajar. 
Marion Joseph Levy. 1996. Modernization and the Structure of Societies: Aspects of Social Structure in Modernized and Non-modernized Societies. New Jersey: Transaction Publishers.

Mastuhu. 1994. Dinamika Sistem Pendidikan Pesantren. Jakarta: INIS.

Mas'ud, Abdurrahman. 2004. Intelektual Pesantren: Perhelatan Agama dan Tradisi. Yogyakarta: LKiS.

Ministry of Religious Affairs of the Republic of Indonesia (http:// www.indonesia.go.id), accessed 3 July 2011.

Qodir, Zuly. 2010. “Gus Dur, NU, dan Perjuangan “Civil Islam”, dalam Gus Dur, Santri Par Excellence: Teladan Sang Guru Bangsa. Jakarta: Penerbit Buku Kompas.

Qomar, Mujamil. 2008. Pesantren: Dari Transformasi Metodologis Menuju Demokratisasi Institusi. Jakarta: Erlangga.

Rahardjo, Dawam. 1985. Pergulatan Dunia Pesantren: Membangun dari Bawah. Jakarta: LP3ES.

Ricklefs, M.C. 2007. Polarising Javanese Society. Singapore: NUS Press.

Soeryopratondo, Soeparlan and M. Syarif. Kapita Selekta Pondok Pesantren. Jakarta: PT Paryu Barokah.

Turmudi, Endang. 2006. Struggling for the Umma: Changing Leadership of Kyai in Jombang, East Java. Canberra: ANU E Press.

van Bruinessen, Martin. 2008. "Traditionalist and Islamist Pesantrens in Contemporary Indonesia", in Ahmad-Noor, et. Al. (Eds.), The Madrasa in Asia: Political Activism and Transnational Linkages. Amsterdam: Amsterdam University Press.

2008. NU Tradisi Relasi-relasi Kuasa: Pencarian Wacana Baru. Jogjakarta: LkiS.

1995. Kitab Kuning: Pesantren dan Tarekat Tradisi-tradisi Islam di Indonesia. Bandung: Mizan.

Yunus, Mahmud. 1985. Sejarah Pendidikan Islam di Indonesia. Jakarta: Hidakarya Agung.

Ziemek, Manfred. 1986. Pesantren dan Perubahan Sosial. Jakarta: LP3ES. 